\title{
Zagrożenia wynikające z jednoczesnego wdrażania inicjatywy lokalnej i budżetu obywatelskiego
}

\author{
Bartłomiej Biga*
}

\begin{abstract}
Streszczenie: $\quad$ Tekst ten jest osadzony w tematyce partycypacji społecznej realizowanej w oparciu o formalne mechanizmy współpracy jednostek samorządu terytorialnego z mieszkańcami i ich zrzeszeniami. Celem opracowania jest wskazanie zagrożeń wynikających z jednoczesnego wdrażania inicjatywy lokalnej i budżetu obywatelskiego. Przedstawione w nim są także propozycje rozwiązań mające minimalizować ryzyko wystąpienia negatywnych zjawisk w tym kontekście. Jest to wynik doświadczeń związanych z wdrażaniem tytułowych instrumentów w różnych gminach. Zasadnicze trudności w tym obszarze wynikają w dużej mierze z braku zaufania na linii administracja - obywatel (i to w obu kierunkach). Ponadto budżet obywatelski, jako instrument umożliwiający obywatelom realizowanie określonych celów przy mniejszym własnym zaangażowaniu, nie może być wdrażany w sposób konkurencyjny względem inicjatywy lokalnej. Niniejszy tekst zawiera więc propozycję komplementarnego wprowadzenia omawianych instrumentów.
\end{abstract}

Słowa kluczowe: inicjatywa lokalna, budżet obywatelski, budżet partycypacyjny, społeczeństwo obywatelskie.

\section{Wprowadzenie}

Wiele jednostek samorządu terytorialnego (dalej: JST) widzi potrzebę wdrażania przynajmniej kilku mechanizmów współpracy z mieszkańcami i organizacjami pozarządowymi. Zwykle jest to podyktowane dążeniem do zwiększenia zaangażowania obywateli w sprawy lokalne, budowy społeczeństwa obywatelskiego, czy bardziej efektywnego wykorzystania środków publicznych. W jednoczesną implementację dwóch szczególnie popularnych mechanizmów budżetu obywatelskiego oraz inicjatywy lokalnej - wpisane jest jednak duże ryzyko skonsumowania całej aktywności obywatelskiej przez pierwszy z nich, przy jednoczesnym nasileniu się u mieszkańców postawy roszczeniowej. Z punktu widzenia obywatela, budżet partycypacyjny pozwala bowiem osiągnąć te same cele przy znacznie mniejszym własnym zaangażowaniu.
Nie jest to jednak argument przeciwko inicjatywie lokalnej, która pod pewnymi warunkami może być także niezwykle użytecznym narzędziem. Konieczne jest jednak dokonanie takiej implementacji omawianych narzędzi, żeby miały one względem siebie charakter komplementarny, a nie konkurencyjny. Wskazanie rozwiązań służących osiągnięciu tego celu jest przedmiotem niniejszego tekstu. Przedstawiane propozycje są efektem rozważań teoretycznych podejmowanych w konwencji ekonomicznej analizy prawa oraz doświadczeń zgromadzonych przy wdrażaniu tytułowych instrumentów w kilkunastu JST w ramach projektu „Wzmocnienie mechanizmów współpracy finanso-

\footnotetext{
* Bartłomiej Biga

Katedra Gospodarki i Administracji Pubicznej Uniwersytet Ekonomiczny w Krakowie

ul. Rakowicka 27, 31-510 Kraków

e-mail: bartlomiej.biga@uek.krakow.pl
} 
wej administracji publicznej z organizacjami pozarządowymi jako realizatorami zadań publicznych" (dalej: MWF).

Warunkiem koniecznym sukcesu wdrażania tytułowych mechanizmów jest jednak zaufanie, rozumiane jako dwustronna relacja: administracja (samorząd) - obywatel (sektor pozarządowy). Wymóg ten jest zbieżny z podstawami wdrażania ekonomii społecznej i wszelkich przejawów działań o charakterze partycypacyjnym. Budowanie takiego dialogu powinno odbywać się głównie w oparciu o narzędzia partnerstwa - zawieranego zarówno $\mathrm{w}$ formie formalnie powoływanych paktów, jak i grup nieformalnych. Podstawą dla dialogu będzie tu wymiana informacji, wspólne omawianie problemów i propozycji rozwiązań oraz otwartość na nowych członków grupy [Zachodniopomorska, 2009, s. 11]. Z tego powodu implementacja inicjatywy lokalnej i budżetu obywatelskiego jest istotna w kontekście kreowania korzystnego kontekstu dla rozwoju ekonomii społecznej na szczeblu lokalnym.

\section{Inicjatywa lokalna}

Inicjatywę lokalną można określić w kategoriach przedsięwzięcia, w którym mieszkańcy danej jednostki samorządu terytorialnego zgłaszają władzom lokalnym postulat realizacji zadania publicznego. Jako podstawowy cel tego mechanizmu wskazuje się natomiast pobudzanie aktywności obywateli nakierowanej na współudział w rozwiazywaniu spraw kluczowych dla danej społeczności [Makowski, Sobiesiak, 2011, s. 40].

Inicjatywa lokalna w swoich założeniach ma umożliwiać odpowiedź mieszkańców na pojawiające się problemy i potrzeby. Nie chodzi tu jedynie o włączenie się społeczności lokalnej na etapie wnioskowania, zgłaszania propozycji działań, ale również o jej aktywność w zakresie realizacji zadania publicznego. Zgodnie z ustawą o działalności pożytku publicznego i o wolontariacie współudział taki może przyjąć formę świadczeń pieniężnych, rzeczowych lub świadczenia pracy społecznej. W praktyce zapis ten oznacza obligatoryjne wskazanie co najmniej jednej z form współdziałania [Biga, Pokora, Schimanek, 2015, s. 72].

\section{Budżet obywatelski (partycypacyjny)}

Budżet obywatelski jest definiowany jako proces decyzyjny, w ramach którego mieszkańcy współtworzą budżet danego miasta (gminy), tym samym współdecydując o dystrybucji określonej puli środków publicznych [Kębłowski, 2013, s. 8]. Brak jest jasnej podstawy prawnej dla tego instrumentu. JST opierają się więc na przepisach art. 5 ustawy o samorządzie gminnym oraz art. 3d ustawy o samorządzie powiatowym, które konstytuują możliwość prowadzenia w sprawach ważnych konsultacji z mieszkańcami. Jest to praktyka zasługująca na pozytywną ocenę. Szerokie rozumienie instytucji konsultacji jest koherentne z zasadami Konstytucji RP, jak i Europejskiej Karty Samorządu Lokalnego [Madej, 2015, s. 211-214].

Proces budżetu obywatelskiego składa się z reguły z czterech etapów [Sześciło i inni, 2014, s. 45]:

1. Zgłaszanie przez mieszkańców i organizacje pozarządowe propozycji projektów do budżetu obywatelskiego za pośrednictwem wystandaryzowanych formularzy.

2. Weryfikacja formalna propozycji przez przedstawicieli urzędu gminy lub doraźną komisję rady gminy - w większości przypadków weryfikacja ogranicza się do zbadania zgodności projektów z obowiązującym prawem (np. treścią miejscowego planu zagospodarowania przestrzennego).

3. Sformułowanie listy projektów pod głosowanie mieszkańców.

4. Głosowanie mieszkańców (internetowo, osobiście w wyznaczonych punktach przypominających lokale obwodowych komisji wyborczych). 


\section{Fundusz Sołecki}

W tym kontekście warto także przywołać instrument, który stał się inspiracją dla powstania budżetu obywatelskiego. Jedną z idei przyświecających wdrażaniu budżetu obywatelskiego była bowiem ekstrapolacja dobrych doświadczeń z funkcjonowaniem funduszy sołeckich na obszary miejskie.

Analiza wniosków zgłaszanych w ramach funduszu sołeckiego pozwala zauważyć, że przedmiotem szczególnej troski mieszkańców jest estetyka przestrzeni publicznej oraz kultywowanie tradycji dożynkowych i strażackich. Wydatki na te kategorie kosztów stanowią istotną część kosztów w większości sołectw. Nie trudno więc wskazać wiele wymiernych i trwałych korzyści dla mieszkańców, jakie wygenerował fundusz sołecki. Estetyka terenów wiejskich, ich funkcjonalność i atrakcyjność stoją - w dużej mierze dzięki funduszowi sołeckiemu - na wysokim poziomie. Nie można oczywiście także bagatelizować doraźnych zadań realizowanych w oparciu o fundusze uzyskane w tym trybie. Przyczynia się to bowiem istotnie do integracji mieszkańców i może być początkiem angażowania ich w inne - bardziej złożone przejawy aktywności obywatelskiej.

\section{Postawy mieszkańców}

Trudno jednoznacznie ocenić poziom rozwoju społeczeństwa obywatelskiego w Polsce. Największą barierą $w$ jego rozwoju wydaje się być bardzo niski poziom zaufania. Najczęściej w tym kontekście mówi się o braku zaufania obywateli do władzy publicznej. Nie sposób jednak pominąć także faktu, iż odwrotna relacja, tj. zaufanie władzy do obywateli, jest na równie niskim poziomie. W Polsce proces budowania zaufania jest z umiarkowanym powodzeniem reailizowany od ponad 20 lat. Można jednak zaobserwować już szereg dobrych efektów tych działań [por. Ćwiklicki, Frączek, 2013].
Formuła cytowanego wyżej opracowania będącego atlasem dobrych praktyk wiąże się z ograniczoną reprezentatywnością opisywanych tam doświadczeń. Agregacja większej liczby przypadków - chociażby analiza średniej frekwencji w głosowaniu na projekty w ramach budżetów obywatelskich - skłania raczej do wniosku, że poziom obywatelskiej aktywności jest umiarkowany bądź niski. Jak wynika z danych zgromadzonych na portalu budzetyobywatelskie.pl - w 2015 r. średnia frekwencja w głosowaniu wynosiła 19,60\% uprawnionych (liczba uprawnionych określona na bazie danych Państwowej Komisji Wyborczej). Naturalnie, wyniki te nie uprawniają do wysuwania daleko idących wniosków, tym bardziej, że dobór samorządów w tym zestawieniu wydaje się być dosyć przypadkowy. Konieczne byłoby też chociażby skorelowanie tych danych z ilością zgłaszanych projektów oraz dokonaniem analizy w ujęciu dynamicznym ${ }^{1}$. Wykracza to jednak poza cel niniejszego opracowania. Przytoczone dane mają jedynie wskazać kontekst społeczny, w jakim wdrażane są instrumenty budżetu obywatelskiego i inicjatywy lokalnej.

\footnotetext{
W literaturze proponuje się, aby badając aktywność lokalną wyróżniać dwa typy uczestnictwa. O biernym uczestnictwie mówi się wtedy, gdy ktoś jest jedynie obserwatorem pewnych wydarzeń, o czynnym - gdy jest jednocześnie aktywnym podmiotem działań. Rozróżnienie to jest istotne z dwóch powodów: po pierwsze pozwala ująć wiele zachowań o charakterze partycypacyjnym i odróżnić je od braku udziału w życiu publicznym, a po drugie daje możliwość zupełnie innego spojrzenia na uczestnictwo bierne i czynne [Pietraszko-Furmanek, 2012, s. 85].
} 
Tabela 1. Frekwencja w głosowaniach budżetów obywatelskich w 2015 r.

\begin{tabular}{|c|c|c|c|c|c|c|}
\hline Lp. & Nazwa samorządu & $\begin{array}{l}\text { Frekwencja } \\
\text { w \% }\end{array}$ & $\begin{array}{c}\text { Liczba } \\
\text { głosujących }\end{array}$ & $\begin{array}{l}\text { Liczba osób } \\
\text { uprawnionych }\end{array}$ & Rodzaj & Województwo \\
\hline 1 & $\begin{array}{l}\text { Miasto Gorzów } \\
\text { Wielkopolski }\end{array}$ & 51,09 & 50216 & 98299 & $\begin{array}{l}\text { m. na prawach } \\
\text { powiatu }\end{array}$ & lubuskie \\
\hline 2 & Miasto i Gmina Stary Sącz & 49,08 & 8957 & 18250 & $\begin{array}{l}\text { gmina miejsko- } \\
\text { wiejska }\end{array}$ & małopolskie \\
\hline 3 & Miasto Zduńska Wola & 46,26 & 16120 & 34843 & gmina miejska & łódzkie \\
\hline 4 & Miasto Piła & 43,94 & 25730 & 58557 & gmina miejska & wielkopolskie \\
\hline 5 & Miasto i Gmina Czersk & 43,74 & 7185 & 16426 & $\begin{array}{l}\text { gmina miejsko- } \\
\text { wiejska }\end{array}$ & pomorskie \\
\hline 6 & Miasto Przemyśl & 41,26 & 21648 & 52467 & $\begin{array}{l}\text { m. na prawach } \\
\text { powiatu }\end{array}$ & podkarpackie \\
\hline 7 & Miasto i Gmina Olkusz & 39,29 & 16024 & 40783 & $\begin{array}{l}\text { gmina miejsko- } \\
\text { wiejska }\end{array}$ & małopolskie \\
\hline 8 & Miasto Tarnów & 37,25 & 34590 & 92870 & $\begin{array}{l}\text { m. na prawach } \\
\text { powiatu }\end{array}$ & małopolskie \\
\hline 9 & Miasto i Gmina Kęty & 36,95 & 10079 & 27277 & $\begin{array}{l}\text { gmina miejsko- } \\
\text { wiejska }\end{array}$ & małopolskie \\
\hline 10 & Miasto Kielce & 31,59 & 51536 & 163125 & $\begin{array}{l}\text { m. na prawach } \\
\text { powiatu }\end{array}$ & świętokrzyskie \\
\hline 11 & Miasto Wrocław & 30,55 & 153000 & 500854 & $\begin{array}{l}\text { m. na prawach } \\
\text { powiatu }\end{array}$ & dolnośląskie \\
\hline 12 & Miasto Włocławek & 29,05 & 27000 & 92953 & $\begin{array}{l}\text { m. na prawach } \\
\text { powiatu }\end{array}$ & kujawsko-pomorskie \\
\hline 13 & Miasto Wągrowiec & 27,96 & 5562 & 19896 & gmina miejska & wielkopolskie \\
\hline 14 & Miasto Mrągowo & 27,45 & 4871 & 17742 & gmina miejska & warmińsko-mazurskie \\
\hline 15 & Miasto i Gmina Kórnik & 24,99 & 4276 & 17109 & $\begin{array}{l}\text { gmina miejsko- } \\
\text { wiejska }\end{array}$ & wielkopolskie \\
\hline 16 & Miasto Zabrze & 22,85 & 32000 & 140015 & $\begin{array}{l}\text { m. na prawach } \\
\text { powiatu }\end{array}$ & śląskie \\
\hline 17 & Miasto Hajnówka & 22,53 & 4168 & 18502 & gmina miejska & podlaskie \\
\hline 18 & Gmina Unisław & 22,43 & 1200 & 5349 & gmina wiejska & kujawsko-pomorskie \\
\hline 19 & Miasto Koszalin & 21,45 & 18569 & 86561 & $\begin{array}{l}\text { m. na prawach } \\
\text { powiatu }\end{array}$ & zachodniopomorskie \\
\hline 20 & $\begin{array}{l}\text { Gmina Jerzmanowice- } \\
\text { Przeginia }\end{array}$ & 21,32 & 1840 & 8632 & gmina wiejska & małopolskie \\
\hline 21 & Miasto Olsztyn & 17,69 & 23830 & 134724 & $\begin{array}{l}\text { m. na prawach } \\
\text { powiatu }\end{array}$ & warmińsko-mazurskie \\
\hline 22 & Miasto Toruń & 17,36 & 27281 & 157175 & $\begin{array}{l}\text { m. na prawach } \\
\text { powiatu }\end{array}$ & kujawsko-pomorskie \\
\hline 23 & Miasto Białystok & 17,31 & 39610 & 228876 & $\begin{array}{l}\text { m. na prawach } \\
\text { powiatu }\end{array}$ & podlaskie \\
\hline
\end{tabular}




\begin{tabular}{|c|c|c|c|c|c|c|}
\hline Lp. & Nazwa samorządu & $\begin{array}{c}\text { Frekwencja } \\
\text { w \% }\end{array}$ & $\begin{array}{c}\text { Liczba } \\
\text { głosujących }\end{array}$ & $\begin{array}{l}\text { Liczba osób } \\
\text { uprawnionych }\end{array}$ & Rodzaj & Województwo \\
\hline 24 & Miasto Zakopane & 17,19 & 3931 & 22874 & $\begin{array}{l}\text { m. na prawach } \\
\text { powiatu }\end{array}$ & małopolskie \\
\hline 25 & Miasto Lublin & 17,15 & 47000 & 274125 & $\begin{array}{l}\text { m. na prawach } \\
\text { powiatu }\end{array}$ & lubelskie \\
\hline 26 & Miasto Sopot & 15,41 & 4800 & 31145 & $\begin{array}{l}\text { m. na prawach } \\
\text { powiatu }\end{array}$ & pomorskie \\
\hline 27 & Miasto Rzeszów & 15,23 & 21730 & 142640 & $\begin{array}{l}\text { m. na prawach } \\
\text { powiatu }\end{array}$ & podkarpackie \\
\hline 28 & Miasto Łomża & 15,12 & 7488 & 49512 & $\begin{array}{l}\text { m. na prawach } \\
\text { powiatu }\end{array}$ & podlaskie \\
\hline 29 & Miasto Sosnowiec & 14,82 & 25692 & 173346 & $\begin{array}{l}\text { m. na prawach } \\
\text { powiatu }\end{array}$ & śląskie \\
\hline 30 & Powiat Wągrowiecki & 13,87 & 7529 & 54272 & powiat & wielkopolskie \\
\hline 31 & Miasto Jelenia Góra & 13,55 & 9100 & 67145 & $\begin{array}{l}\text { m. na prawach } \\
\text { powiatu }\end{array}$ & dolnośląskie \\
\hline 32 & Miasto Głogów & 13,18 & 7251 & 55033 & gmina miejska & dolnośląskie \\
\hline 33 & Miasto Słupsk & 12,84 & 9632 & 74991 & $\begin{array}{l}\text { m. na prawach } \\
\text { powiatu }\end{array}$ & pomorskie \\
\hline 34 & Miasto Jaworzno & 12,83 & 9744 & 75944 & $\begin{array}{l}\text { m. na prawach } \\
\text { powiatu }\end{array}$ & śląskie \\
\hline 35 & Miasto Warszawa & 12,41 & 166893 & 1345374 & $\begin{array}{l}\text { m. na prawach } \\
\text { powiatu }\end{array}$ & mazowieckie \\
\hline 36 & Miasto Bielsk Podlaski & 11,94 & 2616 & 21912 & gmina miejska & podlaskie \\
\hline 37 & Miasto Kraków & 11,41 & 67320 & 589845 & $\begin{array}{l}\text { m. na prawach } \\
\text { powiatu }\end{array}$ & małopolskie \\
\hline 38 & Miasto Puławy & 11,18 & 4509 & 40347 & gmina miejska & lubelskie \\
\hline 39 & Gmina Czerwonak & 11,08 & 2288 & 20650 & gmina wiejska & wielkopolskie \\
\hline 40 & Miasto Gdańsk & 10,63 & 37965 & 357280 & $\begin{array}{l}\text { m. na prawach } \\
\text { powiatu }\end{array}$ & pomorskie \\
\hline 41 & Miasto i Gmina Wołomin & 10,32 & 4132 & 40053 & $\begin{array}{l}\text { gmina miejsko- } \\
\text { wiejska }\end{array}$ & mazowieckie \\
\hline 42 & Miasto Legnica & 10,19 & 8182 & 80324 & $\begin{array}{l}\text { m. na prawach } \\
\text { powiatu }\end{array}$ & dolnośląskie \\
\hline 43 & Miasto Elbląg & 9,94 & 9649 & 97070 & $\begin{array}{l}\text { m. na prawach } \\
\text { powiatu }\end{array}$ & warmińsko-mazurskie \\
\hline 44 & Miasto Radom & 9,4 & 16389 & 174354 & $\begin{array}{l}\text { m. na prawach } \\
\text { powiatu }\end{array}$ & mazowieckie \\
\hline 45 & Miasto Jarosław & 9,11 & 2917 & 32018 & gmina miejska & podkarpackie \\
\hline 46 & Miasto Lębork & 8,07 & 2220 & 27519 & gmina miejska & pomorskie \\
\hline 47 & Miasto Częstochowa & 7,9 & 14919 & 188799 & $\begin{array}{l}\text { m. na prawach } \\
\text { powiatu }\end{array}$ & śląskie \\
\hline
\end{tabular}


BARTŁOMIEJ BIGA: ZAGROŻENIA WYNIKAJĄCE Z JEDNOCZESNEGO WDRAŻANIA INICJATYWY LOKALNEJ...

\begin{tabular}{|l|l|c|c|c|l|l|}
\hline Lp. & \multicolumn{1}{|c|}{ Nazwa samorządu } & $\begin{array}{c}\text { Frekwencja } \\
\text { w \% }\end{array}$ & $\begin{array}{c}\text { Liczba } \\
\text { głosujących }\end{array}$ & $\begin{array}{c}\text { Liczba osób } \\
\text { uprawnionych }\end{array}$ & Rodzaj & Województwo \\
\hline 48 & Miasto Tarnobrzeg & 5,53 & 2186 & 39550 & $\begin{array}{l}\text { m. na prawach } \\
\text { powiatu }\end{array}$ & podkarpackie \\
\hline 49 & Miasto i Gmina Rawicz & 5,24 & 1286 & 24560 & $\begin{array}{l}\text { gmina miejsko- } \\
\text { wiejska }\end{array}$ & wielkopolskie \\
\hline 50 & Miasto Konin & 3,35 & 2104 & 62760 & $\begin{array}{l}\text { m. na prawach } \\
\text { powiatu }\end{array}$ & wielkopolskie \\
\hline 51 & Miasto Ruda Śląska & 3,25 & 3639 & 112031 & $\begin{array}{l}\text { m. na prawach } \\
\text { powiatu }\end{array}$ & śląskie \\
\hline 52 & Miasto Kościerzyna & 1,57 & 286 & 18273 & gmina miejska & pomorskie \\
\hline 53 & Miasto Rybnik & 1,56 & 1720 & 110024 & $\begin{array}{l}\text { m. na prawach } \\
\text { powiatu }\end{array}$ & śląskie \\
\hline
\end{tabular}

Żródło: http://budzetyobywatelskie.pl/2015-frekwencja-w-glosowaniu/ (dostęp: 17.08.2016).

Konieczna jest zatem świadomość, że trudno zmobilizować dużą część mieszkańców nawet do nieabsorbującej współpracy z JST. W tym kontekście oczywisty wydaje się być wniosek, wynikający także z naturalnego ludzkiego dążenia do osiągania celów przy najmniejszym poziomie nakładów, iż mieszkańcy mając możliwość realizacji pewnych zadań przy pomocy różnych narzędzi współpracy z samorządem, nie będą skłonni korzystać z innego, niż najmniej dla nich absorbujący. Wspomniana wyżej oczywista konstatacja często nie jest dostrzegana przez JST wdrażające jednocześnie budżet obywatelski i inicjatywę lokalną.

\section{Postawy przedstawicieli władzy samorządowej}

Jak wynika z rozmów przeprowadzanych z samorządowcami w ramach projektu MWF, w kontekście mechanizmów omawianych w tym tekście obawiają się oni zasadniczo trzech kategorii okoliczności:

A. Roszczeniowej postawy obywateli.

B. Współodpowiedzialności za mogące się pojawić nadużycia.

C. Podejmowania działań wykraczających poza typowy zakres obowiązków urzędnika.
Powyższe wyliczenie nie odbiega zasadniczo od typowych obaw urzędników niższych szczebli. W kontekście tematu podejmowanego w niniejszym artykule, okoliczności te wzmacniają jednak dodatkowo potrzebę precyzyjnego przygotowania treści uchwał dot. budżetu obywatelskiego i inicjatywy lokalnej.

Ad A. Jednym z zabezpieczeń przed negatywnymi skutkami postawy roszczeniowej jest klarowne wpisanie do stosownych uchwał zakresu obowiązków inicjatorów/zgłaszających oraz wskazanie zakresu zadań urzędu wraz z wyraźnie wyliczonymi okolicznościami, które leżą poza gestią samorządu. Jest to więc problem, który w zasadniczej części mieści się w obszarze komunikacyjnym. Przedstawicielom JST biorących udział w projekcie MWF było proponowane informowanie o wprowadzanych narzędziach współpracy na trzech poziomach szczegółowości. Celem pierwszego komunikatu powinno być wzbudzenie zainteresowania mieszkańców i skłonienie ich do sięgnięcia do bardziej szczegółowych informacji. Powinien on mieć postać graficzną (np. diagram), akcentującą potencjalne korzyści dla społeczności. Drugi poziom szczegółowości, to dokument o objętości 1-2 stron, przedstawiający prostym (nieprawniczym) językiem najważniejsze informacje dotyczące narzędzia oraz 
trzeci - najbardziej szczegółowy - którym jest

już sama uchwała wraz załącznikami.

Rysunek 1. Przykład ogólnego komunikatu informacyjnego o inicjatywie lokalnej

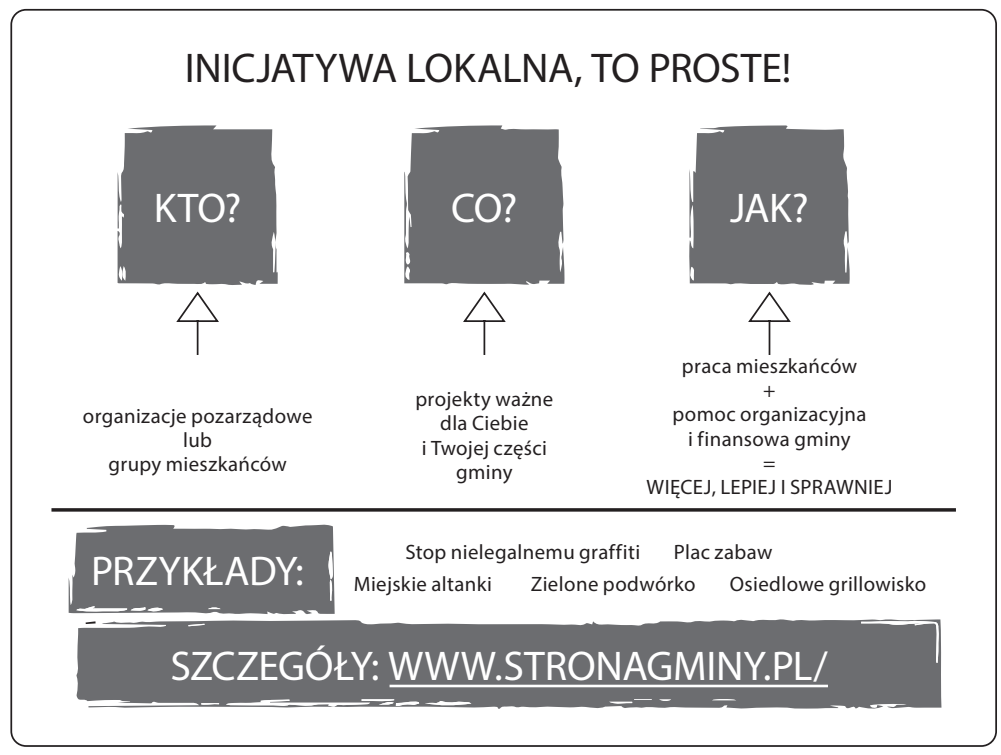

Źródło: opracowanie własne.

Ad B. Drugą, również typową, obawą jest reakcja organów kontroli i nadzoru na działania, które wyłamują się ze standardów. Trzeba podkreślić, że ta niepewność jest $w$ dużej mierze uzasadniona, gdyż praktyka projektów zgłaszanych do budżetu obywatelskiego w wielu gminach zawiera szereg przedsięwzięć kreowanych pod zamówienia w konkretnych przedsiębiorstwach. Ryzyko to musi być więc minimalizowane - wpierw na etapie selekcji wniosków, następnie przy kontroli uczciwego przebiegu głosowania i wreszcie $\mathrm{w}$ fazie wyboru podmiotu realizującego wybrany przez mieszkańców projekt. Naturalnie, przełamanie tej obawy musi się wiązać także z gotowością do podejmowania przez urzędników działań twórczych, z czym wiąże się kwestia przyjmowania odpowiedzialności. Wykształcenie takich zachowań jest zaś możliwe tylko w przypadku dobrze zbilansowa- nego systemu pozytywnych i negatywnych bodźców motywacyjnych.

Ad C. Jedną z głównych przypadłości polskiej administracji jest jej zamknięcie na nowe formy działania. W nowoczesnym państwie natomiast dominująca wcześniej aktywność w sferze imperium traci swoją pozycję na rzecz form bardziej konsensualnych i nieszablonowych. To zjawisko jest szczególnie widoczne w kontekście mechanizmów współpracy JST z mieszkańcami i organizacjami pozarządowymi. W sposób oczywisty wiąże się to z koniecznością podejmowania przez urzędników takich działań, które wykraczają poza typowe czynności realizowane w procesie stosowania prawa. Przełamanie niechęci do takich „nowych" obowiązków wydaje się być niemożliwe bez szeregu działań - szkoleń, bodźców motywacyjnych, promowania dobrych praktyk, itp. 


\section{Współistnienie inicjatywy lokalnej i budżetu obywatelskiego}

Na tej bazie możliwe jest podjęcie próby rozwiązania problemów określonych w tytule niniejszego tekstu. Trudności te w znacznym stopniu wynikają bowiem z przedstawionych wyżej postaw obu stron potencjalnej współpracy. Nie da się ukryć, że w dużej mierze problemy te mają charakter uniwersalny, a przy tym złożony. Dotyczą one wszak licznych sfer aktywności i dlatego skuteczna walka z owymi mankamentami może przynieść skutki w bardzo wielu obszarach. Przytoczenie powyższych dysfunkcji było konieczne, gdyż stanowią one kontekst będący źródłem zasadniczego niebezpieczeństwa skonsumowania inicjatywy lokalnej przez budżet obywatelski. Bez jego zrozumienia i włączenia postulowanych poniżej zmian w działania o charakterze systemowym, trudno też liczyć na sukces we wdrażaniu budżetu obywatelskiego i inicjatywy lokalnej. Zasadniczym celem tego tekstu jest jednak analiza swoistych problemów związanych ze współistnieniem tytułowych mechanizmów.

$\mathrm{Na}$ rekomendację zasługuje więc jasne rozdzielenie zakresu spraw, które mogą być zrealizowane przy pomocy każdego z tych instrumentów. W istocie będzie to wydzielenie pewnych kategorii, które będą mogły być realizowane $w$ ramach inicjatywy lokalnej, przy jednoczesnym wyłączeniu ich z zakresu przedmiotowego wniosków akceptowanych w budżecie obywatelskim. Trzeba bowiem zaznaczyć, iż owe instrumenty mogą zostać implementowane w formule zapewniającej ich komplementarność lub konkurencyjność ${ }^{2}$. Rywalizacja inicjatywy lokalnej z budżetem obywatelskim jest jednak

\footnotetext{
Podobnie można traktować dwa inne instrumenty współpracy - pożyczki i poręczenia. Te ze względu na ich znacznie mniejszą popularność od inicjatywy lokalnej i budżetu obywatelskiego, a także z uwagi na fakt, iż w znacznie mniejszym stopniu realizują one ideę partycypacji społecznej, zostały pominięte w niniejszym opracowaniu.
}

skazana na porażkę, gdyż dla mieszkańców o wiele wygodniejsze jest realizowanie projektów w tej drugiej formule, gdyż wymaga ona od nich stosunkowo niewielkiego zaangażowania.

Wdrożenie tytułowych instrumentów powinno mieć więc charakter komplementarny, także ze względu na szereg innych problemów, z jakimi wiąże się wprowadzanie inicjatywy lokalnej w warunkach umiarkowanie rozwiniętego społeczeństwa obywatelskiego, w którym wciąż są żywe negatywne post-sowieckie konotacje. Dostatecznie wiele problemów dostarcza JST przełamywanie w społeczeństwie porównań do czynu społecznego, a wśród urzędników do przyjmowania odpowiedzialności za działania nietypowe, aby jeszcze dodatkowo utrudniać zaistnienie inicjatywy lokalnej przez występowanie konkurencji w postaci budżetu obywatelskiego.

Kategoriami, których charakter dobrze odpowiada idei inicjatywy lokalnej są chociażby działania dotyczące modernizacji obiektów małej architektury, placów zabaw, czy terenów rekreacyjnych, edukacji i oświaty, tudzież ochrony przyrody ${ }^{3}$. Tworzą one bowiem dogodną przestrzeń dla zaangażowania inicjatorów przez pracę społeczną czy świadczenia o charakterze rzeczowym. Paragraf, który może być wykorzystany w uchwale regulującej inicjatywę lokalną realizującą proponowaną tu formułę, może mieć zatem następujące brzmienie:

1. W ramach inicjatywy lokalnej moga być realizowane zadania publiczne wymienione $w$ art. $19 b$ ustawy $w$ zakresie należacym do zadań gminy, obejmujące:

\footnotetext{
Nie można natomiast dopuszczać do sytuacji, w której podstawowe obowiązki gminy - jak np. budowa i utrzymanie dróg, oświetlenie uliczne - są przez władzę przerzucane czy to do budżetu obywatelskiego, czy do inicjatywy lokalnej. Praktyka wycofywania się JST z realizacji tych zadań i argumentowanie, że takie zadanie mogą być realizowane, jeśli będą się cieszyły zainteresowaniem mieszkańców w głosowaniu lub w inicjatywie jest sprzeczne z zasadami prawa oraz obniża poziom zaufania niezbędny do rozwoju mechanizmów współpracy JST z mieszkańcami i ich organizacjami.
} 
1) modernizację i rozbudowę budynków oraz małej architektury, placów zabaw i terenów rekreacyjnych, z zastrzeżeniem ust. 2 ,

2) ochronę przyrody, w tym zieleni (ekologii i ochrony zwierząt oraz ochrony dziedzictwa przyrodniczego),

3) oświatę i edukację.

2. W przypadku, gdy zadanie realizowane jest na terenie niestanowiącym własności Gminy, Inicjator musi zapewnić Gminie prawo dysponowania nieruchomościa na cele budowlane lub korzystania z niej na czas realizacji przedsięwzięcia.

Naturalnie, regulacje te muszą znaleźć swoje odzwierciedlenie w akcie konstytuującym budżet obywatelski. W tym dokumencie musi się bowiem znaleźć wyłączenie tych kategorii spraw, które mogą być realizowane w ramach inicjatywy lokalnej. Jasne wskazywanie przy kampanii informującej o budżecie obywatelskim, które zadania mogą być realizowane w inicjatywie lokalnej może się ponadto przyczynić do popularyzacji obu mechanizmów. Co oczywiste, sam proponowany wyżej zabieg nie gwarantuje powodzenia w implementacji inicjatywy lokalnej. Istotnie zwiększa jednak szansę na jej sukces poprzez eliminację jednego z głównych zagrożeń.

\section{Podsumowanie}

Niewątpliwie zarówno budżet obywatelski, jak i inicjatywa lokalna pełnią istotną rolę w pobudzaniu aktywności obywateli. Jak wynika z analizy autorów opracowania „Partycypacja społeczna w Polsce. Atlas dobrych praktyk" [Ćwiklicki, Frączek, 2013, s. 220] jednym z najskuteczniejszych sposobów zwiększania zainteresowania obywateli sprawami lokalnej społeczności jest organizacja konsultacji społecznych - są one szczególnie ważne na etapie planowania procesów inwestycyj- nych. Gminy nie mogą jednak poprzestawać na tym rodzaju współpracy, który dla obywateli jest najwygodniejszy i najmniej absorbujący. Konsultacje powinny być pierwszym krokiem, który ma stworzyć płaszczyznę wzajemnego zaufania do budowania bardziej zaawansowanej współpracy, jaką jest choćby inicjatywa lokalna.

Jest to konieczne w kontekście budowania odpowiedniego otoczenia dla rozwoju ekonomii społecznej sensu stricto. Skuteczność jej funkcjonowania zależy bowiem w dużym stopniu od zaistnienia dostatecznej internalizacji celów społecznych przez członków lokalnych korporacji. W tym kontekście rola tytułowych narzędzi jest znacząca - może być traktowana jako pierwsze kroki w stronę bardziej trwałych i złożonych przejawów ekonomii społecznej.

Procedury partycypacyjne można podzielić ze względu na kryterium legalności. Zgodnie $z$ nim takie aktywności jak: wybory, referendum gminne, konsultacje społeczne itp., należą do procedur legalnych Nielegalne natomiast obejmują np.: okupacje budynków i pomieszczeń stanowiących mienie komunalne czy nieuprawniony udział w posiedzeniach organów gminy w celu wywierania presji psychicznej wobec członków władz lokalnych [Kulig, 1996, s. 39]. Nie da się ukryć, że umiejętna implementacja odpowiednio szerokiego katalogu legalnych form współdziałania - takich jak chociażby inicjatywa lokalna i budżet obywatelski - znacząco obniża ryzyko sięgnięcia przez społeczeństwo po metody nielegalne. Przyczynia się ponadto do budowy społeczeństwa obywatelskiego i poprawy efektywności wydatkowania środków publicznych. Zatem nie warto rezygnować z wprowadzania inicjatywy lokalnej ze względu na jej potencjalną konkurencyjność z budżetem obywatelskim. Istnieje wszak możliwość komplementarnego współistnienia tych instrumentów. 


\section{Literatura}

Biga B., Pokora M, Schimanek T. (2015). „Mechanizmy finansowej współpracy finansowej jednostek samorządu terytorialnego z organizacjami pozarządowymi - aspekty prawno-formalne", w: S. Mazur, A. Pacut, M. Pokora (red.), Wdrażanie mechanizmów współpracy finansowej jednostek samorzqdu terytorialnego z organizacjami pozarządowymi. MSAP UEK: Kraków.

Ćwiklicki M., Frączek M. (red.) (2013). Partycypacja społeczna w Polsce. Atlas dobrych praktyk. Fundacja Gospodarki i Administracji Publicznej: Kraków.

Kębłowski W. (2013). Budżet partycypacyjny. Krótka instrukcja obsługi. Instytut Obywatelski: Warszawa.

Kulig A. (1996). „Regulacje prawne partycypacji społecznej w gminach", w: G. Prawelska-Skrzypek (red.), Partycypacja obywatelska w życiu społeczności lokalnej. Stan, bariery, rekomendacje. Fundacja Międzynarodowe Centrum Rozwoju Demokracji: Kraków.
Madej B. (2015). „Konsultacje społeczne z mieszkańcami gminy powiatu i województwa", w: Bukowski Z., Komosiński S. (red.), Samorzad terytorialny: wybory, praktyka społeczna, gospodarka lokalna. Wydawnictwo UKW: Bydgoszcz.

Makowski G., Sobiesiak P. (red.) (2011). Prawo a partycypacja publiczna. Bilans monitoringu 2010. Instytut Spraw Publicznych: Warszawa.

Pietraszko-Formanek I. (2012). Partycypacja spoteczna w środowiskach lokalnych. Krakowska Akademia: Kraków.

Sześciło D., Kudłacz M., Chomątowska M. (2014). Instytucjonalno-finansowe uwarunkowania wspótpracy między jednostkami samorzadu terytorialnego a organizacjami pozarządowymi. MSAP UEK: Kraków.

Zachodniopomorska Biblioteka Ekonomii Społecznej (2009). Ekonomia społeczna w kreowaniu polityki lokalnej gmin i powiatów. Stowarzyszenie Czas Przestrzeń Tożsamość: Szczecin.

\section{Threats from the simultaneous implementation of the local initiative and the participatory budget}

Summary: This text is embedded in the concept of social participation implemented through the formal mechanisms of cooperation between local government units and residents (and their associations). The aim of the study is to identify the risk which arises from the simultaneous implementation of a local initiative and a participatory budget. The text offers solutions designed to minimize the risk of adverse incidents in this context, too. This is the result of experience with the implementation these instruments in various municipalities. The essential problems in this area is the lack of trust between administration and citizens (in both directions). Moreover, participatory budget gives a chance for a society to achieve specific goals with less self-involvement. Therefore this instrument cannot be implemented in a competitive manner with local initiative. Thus, the text contains a proposal for a complementary coexistence of these instruments.

Keywords: local initiative, participatory budget, civil society.

\section{Prawa autorskie i licencja / Copyright and License}

Artykuł opublikowano na licencji Creative Commons

Uznanie autorstwa - Użycie niekomercyjne - Bez utworów zależnych 3.0 Polska

http://creativecommons.org/licenses/by-nc-nd/3.0/pl/

This article is published under the terms of the Creative Commons

Attribution - NonCommercial - NoDerivs (CC BY-NC-ND 3.0) License

http://creativecommons.org/licenses/by-nc-nd/3.0/ 